\author{
ALENKA POLAK, JANA RAPUŠ PAVEL, EDITA BAJRAMLIĆ \\ University of Ljubljana \\ Slovenia
}

\title{
APPROACHES, METHODS AND TECHNIQUES USED FOR DEVELOPING EMOTIONAL COMPETENCY IN THE CLASSROOM
}

\begin{abstract}
Polak Alenka, Rapuš Pavel Jana, Bajramlić Edita, Approaches, Methods and Techniques Used for Developing Emotional Competency in the Classroom [Podejścia, metody i techniki rozwoju kompetencji emocjonalnych w klasie]. Studia Edukacyjne nr 34, 2015, Poznań 2015, pp. 325-344. Adam Mickiewicz University Press. ISBN 978-83-232-2896-7. ISSN 1233-6688. DOI: 10.14746/se.2015.34.20

Contemporary educators in schools should possess a number of competences, personal traits, subject knowledge, psychological and pedagogical knowledge, skills and teaching strategies to be able to work with pupils, consider their wide range of learning demands and special needs as well as cope with behavioural and other problems in the classroom. Social pedagogues employed in schools and teachers have to deal with emotions on a daily basis, and so they need to be emotionally intelligent. According to Goleman, major components of emotional intelligence include the awareness of our emotions, managing our own emotions, motivating ourselves, recognizing the emotions of others, empathy, and relationships management. Emotional intelligence in the context of schooling relates to the emotional side of teaching, such as the ability to recognize, define and manage pupils' emotions, to motivate them and to handle interpersonal relationships in the classroom. Emotional competency is the efficacy in social situations with an emotional content. In the article we present an empirically designed study based on data collected in a questionnaire designed for the aim of the study. The research sample includes 108 persons dealing with school pupils on a daily basis; 56 of them are teachers and 52 social pedagogues, employed in the school advisory service. The aim of the study was to investigate how often teachers and social pedagogues use different approaches, methods and techniques for developing the emotional competency of pupils in the classroom. In the article the findings are discussed within the school context and some implications are provided for the higher education of teachers and social pedagogues.
\end{abstract}

Key words: emotional intelligence, emotional competency, teachers, social pedagogues, education

\section{Introduction}

Teachers and social pedagogues are important agents in the education of pupils - future generations of citizens. For an individual to function success- 
fully as part of a society, intellectual parts of personality as well as emotional and social skills are needed. It is of great help for teachers and social pedagogues if they themselves are emotionally competent - able to recognize, understand their own and other people's emotions, and also control them with respect to the circumstances. On that basis they can use several approaches, methods and techniques to promote and develop the emotional competency of the students. In the treatment of the concept of intelligence in expert literature one has to consider that intelligence is culturally dependent, and that it is determined with respect to the needs within a society ${ }^{1}$. Goleman (1997) ${ }^{2}$ emphasizes that a high IQ is not a guarantee for success, as intellect cannot function properly without the use of emotions and the intelligence developed with schooling does not prepare a person for the everyday demands of the modern world. Each person has two kinds of brain, two types of cognition and two distinct intelligences: intellectual and emotional. Cognitive intelligence is thus desired especially in a culture where knowledge and status are complementary values, attained by learning 3 . However, Weishbach and Dachs warn that the classic concept of (cognitive) intelligence does not include capabilities that affect a person's success at important life challenges such as empathy, self-confidence and control of emotions ${ }^{4}$. According to Bradberry and Greaves, cognitive intelligence is constant and does not change during the course of a one's life ${ }^{5}$, while other authors, such as Simmons and Simmons and Goleman state that emotional intelligence is a dynamic component of personality and can be learned, trained and improved ${ }^{6}$. The development of emotional intelligence is affected by a person's experiences, especially emotional experiences during childhood and adolescence ${ }^{7}$.

\section{Emotional intelligence in relation to classic cognitive intelligence}

Traditional understanding of the terms emotion and intelligence is exclusive: psychologists have considered emotion a primitive process and cog-

${ }^{1}$ G. Matthews, M. Zeidner, R.D. Roberts, Emotional Intelligence: science and myth, Cambridge-London 2004.

2 D. Goleman, Čustvena inteligenca: zakaj je lahko pomembnejša od IQ, Ljubljana 1997.

${ }^{3}$ G. Matthews, M. Zeidner, R.D. Roberts, Emotional Intelligence.

${ }^{4} \mathrm{C}$. Weisbach, U. Dachs, Kako razvijamo čustveno inteligenco: razmišljajmo s srcem, Ljubljana 1999.

5 T. Bradberry, J. Greaves, Čustvena inteligenca: kratek vodnik, Ljubljana 2008.

${ }^{6}$ S. Simmons, C.J. Simmons, Merjenje čustvene intelligence, Ljubljana 2000.

7 J. Wharam, Čustvena inteligenca: potovanje v središce samega sebe, Anu Elara, Ig 2012. 
nition a different, evolutionary function. Bracket, Rivers and Salovey agreed with this statement and supported the idea of contradiction between emotion and intelligence ${ }^{8}$. Contemporary theories, however, show that emotions drive cognitive activity and direct our behaviour. Cognitive and emotional sides of personality are thus not in opposition, but are separate competences and often intertwined. Simmons and Simmons believe that emotional intelligence, similarly to the cognitive intelligence, is a brain function and contains the whole person - their cognitive, physical, emotional and behavioural aspects ${ }^{9}$. Emotions guide our behaviour, so that we cannot treat the emotional quotient as opposite to the intelligence quotient, as social, emotional and cognitive skills are all important ${ }^{10}$. Furthermore, an increasing number of studies confirm that for an individual's emotional health and successful relationships at the workplace, traits of emotional intelligence are more important than the intelligence quotient ${ }^{11}$. When considering the concept of emotional intelligence, one should mention Sternberg (1985) who claims that emotional intelligence is practical intelligence, as opposed to academic intelligence and adds that emotional intelligence is useful for solving problems related to one's feelings, needs and plans for survival ${ }^{12}$. The development of the concept of intelligence was also influenced by Gardner's theory of the division of social intelligence into intrapersonal and interpersonal. Gardner describes interpersonal intelligence as the ability of observing differences in temperament, mood, motivation and intentions in other persons, while the core of intrapersonal intelligence (in his opinion) consists of awareness and differentiation of one's own emotions and the ability to use these emotions for directing their own behaviour ${ }^{13}$. The concept of emotional intelligence gained interest as an object of teaching in the 1990's, when Salovey and Mayer first used the concept of emotional intelligence and described it as the ability of assessment, expression and regulation of emotions, both in oneself and in others, and as the ability to use emotions when solving problems and making decisions ${ }^{14}$. The term emotional intelligence became more widely known in 1995, when Goleman authored a book title

8 A.M. Brackett, E.S. Rivers, P. Salovey, Emotional intelligence: implications for personal, social, academic and workplace success, Social and personality psychology Compass 2011, 5.

${ }^{9}$ S. Simmons, C.J. Simmons, Merjenje čustvene intelligence.

${ }_{10}$ R. Wood, H. Tolley, Ocenite svojo čustveno inteligenco: kako določiti in povečati svojo čustveno inteligenco? Ljubljana 2004.

${ }_{11}$ D. Goleman, Čustvena inteligenca.

12 S. Pečjak, A. Avsec, Konstrukt emocionalne inteligentnosti, Psihološka obzorja, 2003, 12/1.

${ }_{13}$ H. Gardner, The frames of mind, Basic Books 1993.

${ }^{14} \mathrm{~V}$. Arghode, Emotional and social intelligence competence: Implications for instruction, International Journal of Pedagogies and Learning, 2014, 8/2. 
Emotional Intelligence. ${ }^{15} \mathrm{He}$ categorized it as a construct consisting of five entities: recognition of emotions, regulation of emotions, self-motivation, recognition of emotions in others, and behaviour in interpersonal relationships. According to his book, an individual has the abilities of recognizing their own emotions and emotions of others, of motivating themselves, and of controlling and regulating their own emotions and emotions of others.

\section{Development of emotional intelligence}

To understand the role of emotional intelligence, one must know how emotional intelligence forms and what affects the development of a person's feelings and behaviour. According to Matthews, Zeidner and Roberts, a study should consider the entire framework of different determinants that affect the development of emotional intelligence. ${ }^{16}$ The impact of genetics or nature as the biological determinant is certainly important, as people inherit certain character traits and tendencies. However, we also inherit basic human needs, such as the needs for sustenance, acceptance and respect. All these needs have an impact on the formation of emotional intelligence. Emotional intelligence could then be described as a repertoire of emotional competences which can be attained and can help us face challenges from the environment. The development of emotional intelligence, however, also depends on education. Some authors highlight the fact that childhood is a critical age for the formation of emotional competences, where education and learning of different behavioural patterns have a strong influence ${ }^{17}$. People involved in the process of primary socialization (usually the parents) can influence their child directly or indirectly. Direct influence is achieved with advising about the use and control of emotions, giving instructions, etc. It is crucial that parents treat unpleasant emotions as opportunities for obtaining competences in the area of dealing with problems. Indirectly, children can learn and assimilate new emotional responses by observing role models and demonstrations of certain behaviour patterns (there). Simmons and Simmons treat the indirect influence of early education as learning on a subconscious level, as an impulse-response link. ${ }^{18}$ This means that an emotionally important event can lead to a generalization of all similar events and causes the individual to respond to similar events in the same way (there).

\footnotetext{
${ }^{15}$ D. Goleman, Čustvena inteligenca.

16 G. Matthews, M. Zeidner, R.D. Roberts, Emotional Intelligence.

17 Ibidem.

18 S. Simmons, C.J. Simmons, Merjenje čustvene intelligence.
} 
Matthews, Zeidner and Roberts believe that the converse effect is also present: children who are deprived of certain emotions begin to suppress these and similar emotions. Authors listed some factors that affect the development of emotional intelligence but are often overlooked in everyday life: (1) personal experience: children gather experiences of how to deal with their own emotions through self-actualization, and these experiences then influence their perception of subsequent events; (2) peers: with growing up, peers become an increasingly important factor for gathering experiences and developing emotional competences; (3) school: the relationship between a student and a teacher is one of the most important experiences for a child. Teachers, with their direct or indirect methods of teaching, can affect the student's ability of expression and emotion control; (4) media: through being exposed to different mass media (television, internet, magazines), children learn how to express themselves, how to control emotions and how to recognize emotional expressions..$^{19}$ Additionally, physical injuries, such as brain defects or chemical changes in the body, such as those caused by the use of certain substances (drugs) can modify a person's emotions.

\section{Emotional competency as behavioural manifestation of emotional intelligence}

Goleman describes emotional competency or literacy as a learned capability, while treating emotional intelligence as potential for learning certain skills. ${ }^{20}$ Term intelligence is used for potentials, which a person can either develop or not, and literacy corresponds to the degree of understanding of emotions, emotional skills and strategies. Shapiro divides the manifesting elements of emotional intelligence into six groups: skills related to (1) moral behaviour, (2) cognition, (3) problem solving, (4) mutual social action, (5) success in school and in the workplace and (6) emotions ${ }^{21}$.

Following Goleman's model of emotional intelligence, M. Panju lists the components of emotional intelligence as (1) self-awareness, (2) self-control, (3) empathy, (4) personal motivation and (5) interpersonal skills.22 She describes self-awareness as the ability of an individual to recognize their emo-

19 G. Matthews, M. Zeidner, R.D. Roberts, Emotional Intelligence.

20 D. Goleman, Working with emotional intelligence, New York-Toronto-London-SydneyAuckland 2000.

${ }^{21}$ E.L. Shapiro, Čustvena inteligenca otrok: kako vzgojimo otroka z visokim čustvenim količnikom, Ljubljana 1999, p. 33.

${ }^{22}$ M. Panju, Strategije za spodbujanje čustvene inteligentnosti v razredu, Ljubljana 2010. 
tions and internal states, to understand the causes of their own emotions and actions, and how they affect themselves and others. Further, she calls selfawareness the basis on which other elements of emotional intelligence stand. For instance, self-awareness is a necessary condition for the development of self-control, as only the knowledge of one's emotions enables the control over one's behavior (there). Wood and Tolley believe that the awareness of one's own emotions means the respect of these emotions and relates to an individual's care for themselves. Balance between accepting one's own emotions and respecting the emotions of others is important. Self-awareness also covers listening to others, which helps us to avoid an excessive selfcenteredness (there). Self-control, defined as the ability to control one's emotions and the non-impulsive parts of one's behaviour, is an important aspect of emotional intelligence. The self-controlled individual is emotional competent when is aware of their emotions before deciding on a certain course of action. However, Wood and Tolley highlight the fact that people are reasonable beings who can avoid impulsive outbursts, so we have control over our own actions and can act appropriately with respect to circumstances. ${ }^{23}$ An important part of emotional intelligence is also an empathy, which some authors consider central for our humanness ${ }^{24}$. Empathy is the ability of perceiving the feelings of other people and understanding their emotions (there). M. Panju describes empathy as the ability of connecting with others and understanding their feelings, whether we share (or agree with) these feelings or not. To be empathic means to be emotionally competent to understand how we would feel in their place. Empathy is connected with a person's abilities of self-awareness, as without knowing our own emotions, we cannot appreciate the emotions of others (there). ${ }^{25}$ The fourth component of emotional intelligence is personal motivation, manifesting in the ability of persisting and striving towards a goal despite obstacles, but also in an optimistic tendency towards achievements, in the coordination with the goals of a group or organization, and in taking initiative and seizing opportunities for achieving certain goals. ${ }^{26}$

Among the components of emotional intelligence according to Goleman's models, are also skills in interpersonal relationships, which are an important ingredient of a complex system of interconnected abilities, as they enable us to build and maintain personal relationships and are instrumental

${ }^{23} \mathrm{R}$. Wood, H. Tolley, Ocenite svojo čustveno inteligenco.

${ }^{24}$ B. Bellhouse, G. Johnson, A. Fuller, Empathy: promoting resilience and emotional intelligence for young people aged 7 to II, London 2005.

${ }^{25} \mathrm{M}$. Panju, Strategije za spodbujanje čustvene inteligentnosti v razredu.

${ }^{26}$ Ibidem. 
for the development of personality in the emotional and intellectual areas. ${ }^{27}$ Based on the opinions of several authors we can conclude that the development of emotional and social skills on the level of awareness of oneself, one's emotions and relationships in society is critical for the development of emotional competency as the manifestation of the emotional intelligence of the individual.

\section{Development of emotional competency using different approaches, methods and techniques in the classroom}

School, as the environment where the process of education takes place, is one of the most important contexts for learning emotional skills and competencies. The relationships established with teachers, peers and with the school affect how a child's reception of social views, convictions and values, as well as the general understanding of society (there). The school counselling service is one of the subsystems with no formal power but with a great amount of informal influence, mostly due to the amount of information available and the sustained contact with other school subsystems (school leadership, students, teachers and parents) as well as institutions outside of the school area (centres for social services, educational consulting services, career centres, other schools, etc.). The work of a counselling service in Slovenia can be performed by people of different professional paths, such as psychologists, pedagogues, social workers, social pedagogues, or special and rehabilitation pedagogues. Their mission is helping individuals and group within the school, as well as cooperating on planning, execution and evaluation of educational work with the intention of contributing to greater success of individuals, groups and the school as a whole ${ }^{28}$. T. Grünfeld more precisely lists the tasks of the school counselling service as: work with newcomers, forming classes, career counselling, testing, help for students with reading and writing disorders, offering individual help to students with family problems, overseeing individual discussions with parents, offering and seeking external help for children in need, organization of cooperation with outside experts and connecting with other institutions, comparison of data for external tests, helping teachers work with educationally or behaviourally

27 R. Wood, H. Tolley, Ocenite svojo čustveno inteligenco, p. 113.

28 S. Pečjak, K. Košir, Povezanost čustvene inteligentnosti z nekaterimi vidiki psihosocialnega funkcioniranja pri učencih osnovne in srednje šole, Psihološka obzorja, 2012, 12/1. 
problematic students; advising and help teachers with the formation of a positive environment in the classroom, including positive relationships between students, organizing workshops and seminars for parents and students, acquainting parents with class problems, cooperating with other social pedagogues and exchange of experiences etc. ${ }^{29}$ In Slovenian elementary school, counselling service workers offer advice and help for individuals, as well as wider groups including students, other school workers, school leadership and parents. Pedagogues in Slovenian school are increasingly faced with behaviour disturbances of young people, with their inability to form genuine contacts with their peers, with peer-to-peer violence. In the wider context of their work, social pedagogues are focused on integrative, supportive, directive and conciliatory functions within the school environment.

The school environment is one of the most important contexts for learning and developing emotional skills and obtaining competences. Systematic learning and training of these skills enable students to acquire competences in the area of expressing and controlling emotions. ${ }^{30}$ Hence, it is important to encourage the students to competently regulate their emotional responses in social interactions - to use their emotional expression and knowledge about emotions when dealing with others. Educators can contribute a great deal to the development of emotional capabilities of children. It is important that they respond to the emotions of children, listen to them, and understand their perception and behaviour. Teachers can grow closer to students by being personally sensitive, by being willing to perceive the world as the students do. ${ }^{31}$ M. Panju notes that it is also important how teachers face their own emotions, especially the negative ones. According to the author (there), successful teachers are those who can deal with their negative emotions in a positive way. By choosing appropriate teaching approaches, methods and techniques they can influence the students with teaching about controlling one's emotions, respecting other people's emotions, resolving conflicts and motivating oneself and others. ${ }^{32}$ According to numerous authors, teaching productivity or the academic success of an individual is still prioritized. Matthews, Zeidner and Roberts find that many teachers believe that their job is to impart academic knowledge on students, so education about emotion and social skills is often met with scepticism. ${ }^{33} \mathrm{M}$. Panju finds that traditional curriculum does not sufficiently prepare the students for facing the

${ }^{29}$ T. Grünfeld, Socialni pedagog v osnovni šoli, Socialna pedagogika, 1997, 1/4.

${ }^{30}$ G. Matthews, M. Zeidner, R.D. Roberts, Emotional Intelligence.

${ }^{31}$ R. Bisquerra Alzina et al., Čustvena inteligenca otrok: priročnik za učitelje in starše z vajami, Ljubljana 2010.

${ }^{32}$ M. Panju, Strategije za spodbujanje čustvene inteligentnosti v razredu.

${ }^{33}$ G. Matthews, M. Zeidner, R.D. Roberts, Emotional Intelligence. 
real world and that the importance of emotion and their role in education should be emphasized. She suggests different methods of stimulating emotional intelligence of students in a classroom. Teachers can achieve this by developing self-awareness, self-control, empathy, personal motivation and interpersonal skills. According to the author, teachers can develop a student's self-awareness with various activities that study the student's selfesteem, expand their vocabulary (e.g. brainstorming, role-play, making collages), encourage the students to describe their emotions and feeling about objects or events, determine the causes and effects of emotions through conversation encourage them to analyze emotions through a journal. Teachers can stimulate self-control in different ways: helping students identify the feelings of anger, give those opportunities to talk about anger-causing relationships, situations or people, talk with the class about anger-management strategies (e.g. positive conversation with oneself, use of humour, relaxing and breathing exercises). It is also important to discuss anger triggers with students. The role model of a teacher who can admit, accept and take responsibility for their own anger, and express it in a direct and nonaggressive way is especially important. Teachers can encourage empathy in students by strengthening their awareness of other people's emotions, by giving them opportunities to think about their own emotions and experiences. They can achieve this by first directing the students towards understanding of their own emotions and through that to putting themselves into the position of another person (with role-playing, discussion, stories, exposure to stimuli that cause certain emotions). In the area of developing personal motivation, M. Panju suggests that teachers have to talk with students about what has to be done to achieve the set goals, but they can also use different methods of rewarding appropriate behaviour. It is important that students are made aware about long-term benefits which can be achieved by postponing instant gratification. To development students' interpersonal skills, a teacher has to enable rich communication within the group, teach them the skill of attentive listening, enable the development of assertive skills, through which they will be able to find an appropriate way of communicating in situations where they are flooding by emotions. The regular use of examples where a teacher talks with a group of students about resolving different problems significantly contributes towards the development of emotional intelligence, as students will then know how to use these example in difficult situations. ${ }^{34}$ 


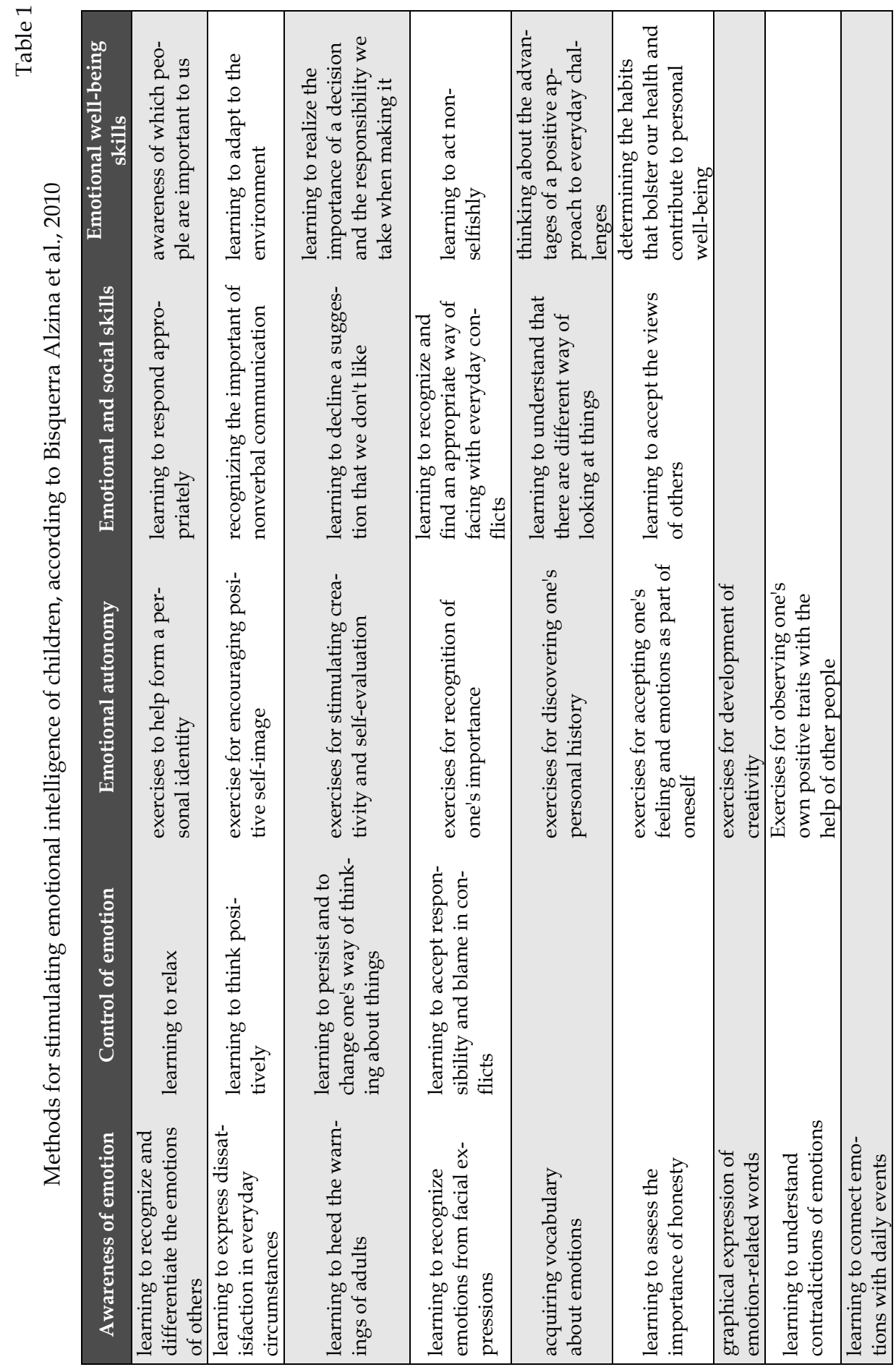


More specific methods for stimulating emotional intelligence of children can be found it Bisquerra Alzina et al. (2010). They believe that the component of self-awareness can be stimulated with graphical expression of words for describing emotions and the connection of emotions with daily events. Self-control of emotions can be stimulated with optimistic thinking about things, accepting responsibility/blame in conflicts, relaxation. Different exercises, such as writing a journal or poems, learning nonverbal communication, and discovering one's personal history can improve the recognition of one's own emotions and emotions of others. ${ }^{35}$ Authors divide the methods for stimulating emotional intelligence of children into multiple sections: awareness of emotions, control of emotions, emotional autonomy, emotional and social skills and skills for emotional well-being (table 1).

According to M. Panju, the primary objective of teaching is the integration of emotional and intellectual learning in students. Emotional intelligence, and emotional competency as its recognizable manifestation, can be stimulated by developing certain skills, such as the skill of conflict resolution, communication skills, interpersonal skills, anger management skills. ${ }^{36}$ The author (there) believes that especially group work (team work, cooperative learning in small groups) should be introduced; because it helps students learn how to build relationships with others in the environment.

\section{The aim of the study}

In this study, we used a quantitative empiric research approach, where we focus on Primary and Lower secondary teachers and social pedagogues working within the school context. Both, teachers and social pedagogues getting their degrees at the Faculty of Education, University of Ljubljana, receive a very reflection-focused education and training, so we conjectured that they would be focused more towards encouraging emotional and social skills than towards academic achievement. In this study, we were interested in how often teachers and social pedagogues use different approaches, methods and techniques to fostering and developing emotional competency of their students. Within the context of the research questions, we predicted that there would be no significant difference between social pedagogues and teachers in the use different approaches, methods and techniques for developing emotional competency of students.

\footnotetext{
${ }^{35}$ R. Bisquerra Alzina et al., Čustvena inteligenca otrok.

${ }^{36}$ M. Panju, Strategije za spodbujanje čustvene inteligentnosti v razredu.
} 


\section{Research sample}

The sample size was consisted of 108 persons, of which $87.61 \%$ were female and $12.39 \%$ male. 56 of them were teachers and 52 social pedagogues, employed in elementary school throughout Slovenia. Their average age was 39.03 years. The average age of the participating teachers was 41.91 years, the average age of the 52 social pedagogues was 36 years. The sample consisted of $21.24 \%$ Primary education teachers, $28.32 \%$ Lower secondary education teachers and $46.02 \%$ social pedagogues. Within the sample, $16.8 \%$ of participants have been employed for up to 3 years, $22.1 \%$ from 4 to10 years, $17.7 \%$ from 11 to 15 years, 15.9 from 16 to 20 years, and $27.4 \%$ have been employed in the area of education for more than 20 years.

\section{Methods}

Data was collected within the questionnaire, constructed on the basis of list of methods for stimulating emotional intelligence designed by Bisquerra Alzina et al. (2010)37. In the scale we constructed for accessing, how often teachers and social pedagogues use these different approaches, methods and techniques to develop emotional competency of students were listed. The answers of participants can differ from 1-never do 5 - very often. The survey was performed in May 2014. Data was collected anonymously and then analyzed using the SPSS statistical software.

\section{Results with discussion}

From Table 2 we can see that both groups often use different approaches, methods or techniques to foster emotional competency of pupils. Both teachers and social pedagogues claim that they most frequently encourage students towards fair and genuine relationships (teachers - 4.50; social pedagogues - 4.65). Based on the arithmetic mean of the frequency of use, the use of different approaches, methods and techniques for encouraging emotional competency is followed by encouraging students towards proper etiquette (teachers - 4.54; social pedagogues - 4.54), encouraging charity and help in the classroom (teachers - 4.29; social pedagogues - 4.54), encouraging of patience and tolerance towards others (teachers -4.43 , social pedagogues -4.48 ).

\footnotetext{
${ }^{37}$ R. Bisquerra Alzina et al., Čustvena inteligenca otrok.
} 
We find that both teachers and social pedagogues assign great importance to encouragement of pro-social behaviour with the emphasis on moral values, expressed with broad and interesting terms (such as fairness, honesty, etiquette, charity, etc.), most commonly related to the desired behaviour (mutual help, tolerance) they are trying to encourage in the classroom. Based on these results we can hardly determine how much teachers and social pedagogues actually encourage the students to think about their own ethics and about what is or isn't ethical. When developing emotional and social competencies, it is vital that students have opportunities for deeper analysis, as well as active and constructive reflection of social experience, and chances for talking about reasons for their ethical decisions. Discussions about interpersonal experiences and thinking about one's views, the views of others and about motives and intentions of one's behaviour should be encouraged to a greater degree, according to Warden and Christie. ${ }^{38}$

On average, teachers and social pedagogues least frequently encourage students to write poems (teachers -2.38 , social pedagogues -2.77 ) and perform different techniques of relaxation with students (teachers - 2.82, social pedagogues - 2.75). Writing poems and other similar techniques stimulate the development of intrapersonal skills of recognizing one's own emotions and the emotions of others. Within this context Sheehan, McDonald and Spence suggest encouraging intrapersonal competency using different methods, such as reflective journal writing, role-playing and group case exercises to indirectly improve students' emotional intelligence. The authors find that experiential activities can have a positive effect on students' emotional competency without formally instructing them on emotional intelligence theory in the classroom. ${ }^{39}$

Based on the results of our survey, we find that both teachers and social pedagogues use relaxation techniques relatively rarely, even though we know that school is one of the central stress-inducing factors and everyday situations at school cause various tensions in students. Data from an international study HBSC (2006) confirms that Slovenian children and adolescents are under stress, as $17 \%$ out of 5130 surveyed children has trouble sleeping more than once a week. The same study show that $20 \%$ of adolescents has problems in the area of emotions, hyperactivity, or behavioural patterns such as quick anger, aggressiveness, disobedience (28\%), while $15 \%$ of adolescents has trouble in the emotional area (fear, depression, worries). ${ }^{40}$ This

38 D. Warden, D. Christie, Spodbujanje socialnega vedenja: dejavnosti za spodbujanje prosocialnih medosebnih spretnosti in vedenja, Ljubljana 2001.

39 B.J. Sheehan, M.A. McDonald, K.K. Spence, Developing Students' Emotional Competency Using the Classroom - as Organization Approach, Journal of Management Education, 2009, 33/1.

${ }^{40} \mathrm{H}$. Jeriček Klajnšček, Ko učenca strese stres in kaj pri tem lahko naredi učitelj. Priročnik za učitelje in svetovalne delavce, Ljubljana 2007, p. 6. 
data warns that including different techniques of relaxation for students is important for reduction of stress. Increasingly high expectations of children, as well as expectations of their parents and their social environment, further contribute to higher stress levels. Children can feel under additional pressure because of the need for proving themselves and succeed at all costs, which is also socially encouraged. This raises the question why teachers and social pedagogues do not include stress-reducing approaches, methods and techniques more often. The answer may lie in the increasingly productivityoriented school, which overlooks the emotional aspects of education, or the fact that pedagogical workers lack the skills and training in this area.

In this research, we were interested whether there are statistically significant differences in the use of different approaches, methods and techniques of developing emotional competencies of students between teachers and social pedagogues. Teachers work with students on a daily basis and thus have a direct contact with them, giving them more opportunities for bringing different approaches, methods and techniques for developing emotional competency into the classroom. Social pedagogues in schools have less frequent contacts with students, but they probably have better developed competencies in the area of knowing "how" - a wide spectrum of approaches, methods and techniques for stimulating development of emotional and social skills in the classroom.

In the programs of education and training of both professional profiles at the Faculty of Education, University of Ljubljana (social pedagogues are educated only at this faculty, while teachers can be educated at one of the three different faculties in Slovenia), the importance of emotional intelligence, emotional competency and their effects of relationships between students is strongly emphasized. Statistically significant differences between teachers and social pedagogues have been found in the frequency of encouraging students to describe their feelings and emotions, in the frequency of reading stories and tales on the topic of emotions and in the frequency of encouraging optimistic thinking. In statements 13, 14 and 26 of the questionnaire we indeed found statistically significant differences between the two groups (table 2). The hypothesis can be confirmed for statement 13 (encouraging students to describe feelings and emotions, related to a certain topic, $\mathrm{p}=0.001$ ) and statement 26 (encouraging of optimistic thinking in the classroom, $\mathrm{p}=0.042$ ), where social pedagogues assessed their use of the respective methods higher than the teachers. For statement 14 (reading stories and tales with the topic of emotion, $\mathrm{p}=0.034$ ), however, teachers rated their use of this method higher than social pedagogues. 


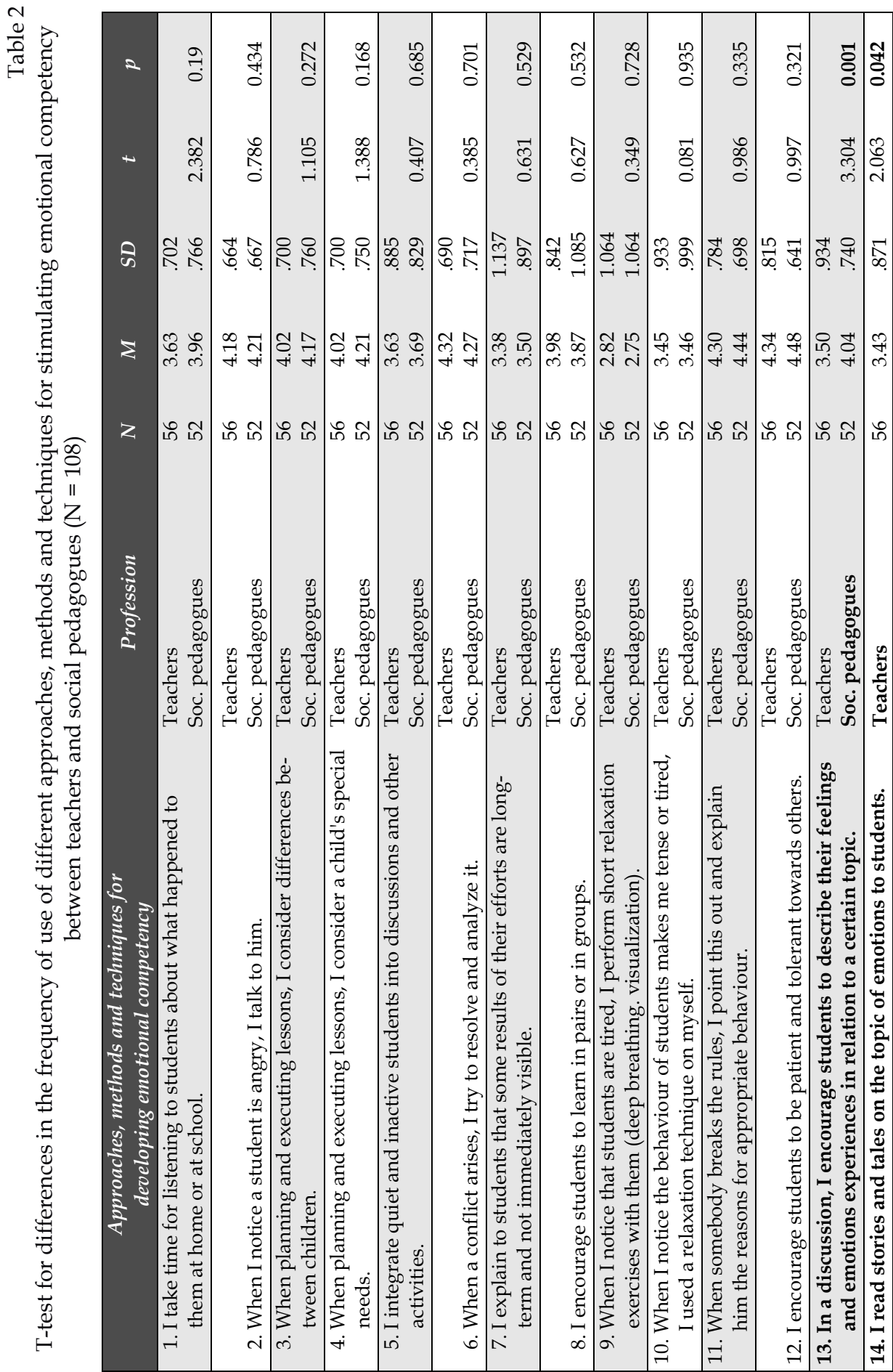




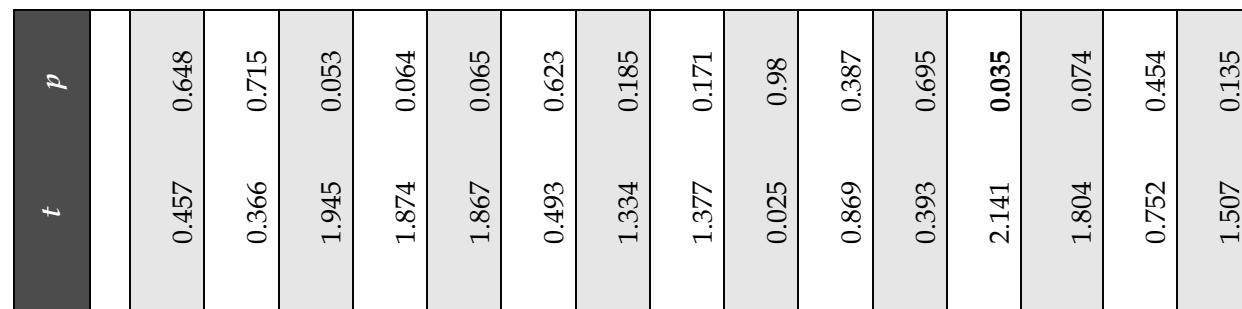

की

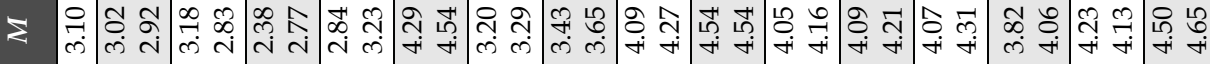

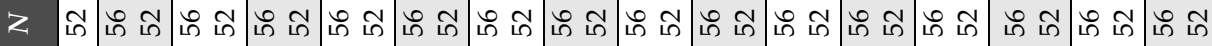

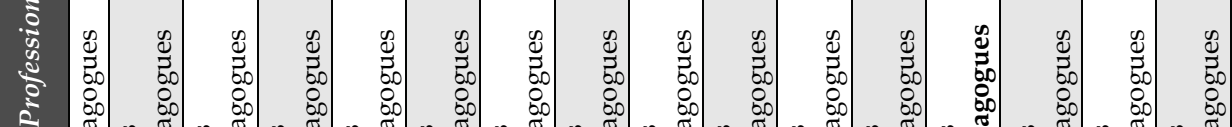

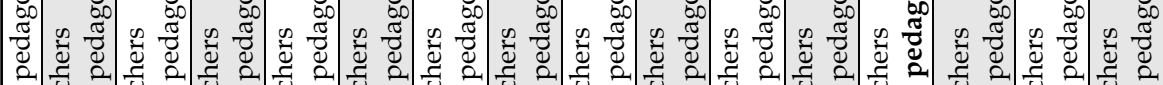

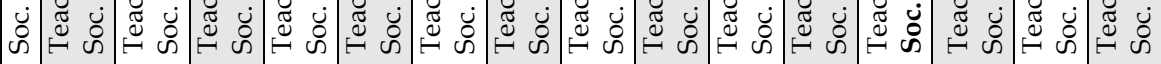

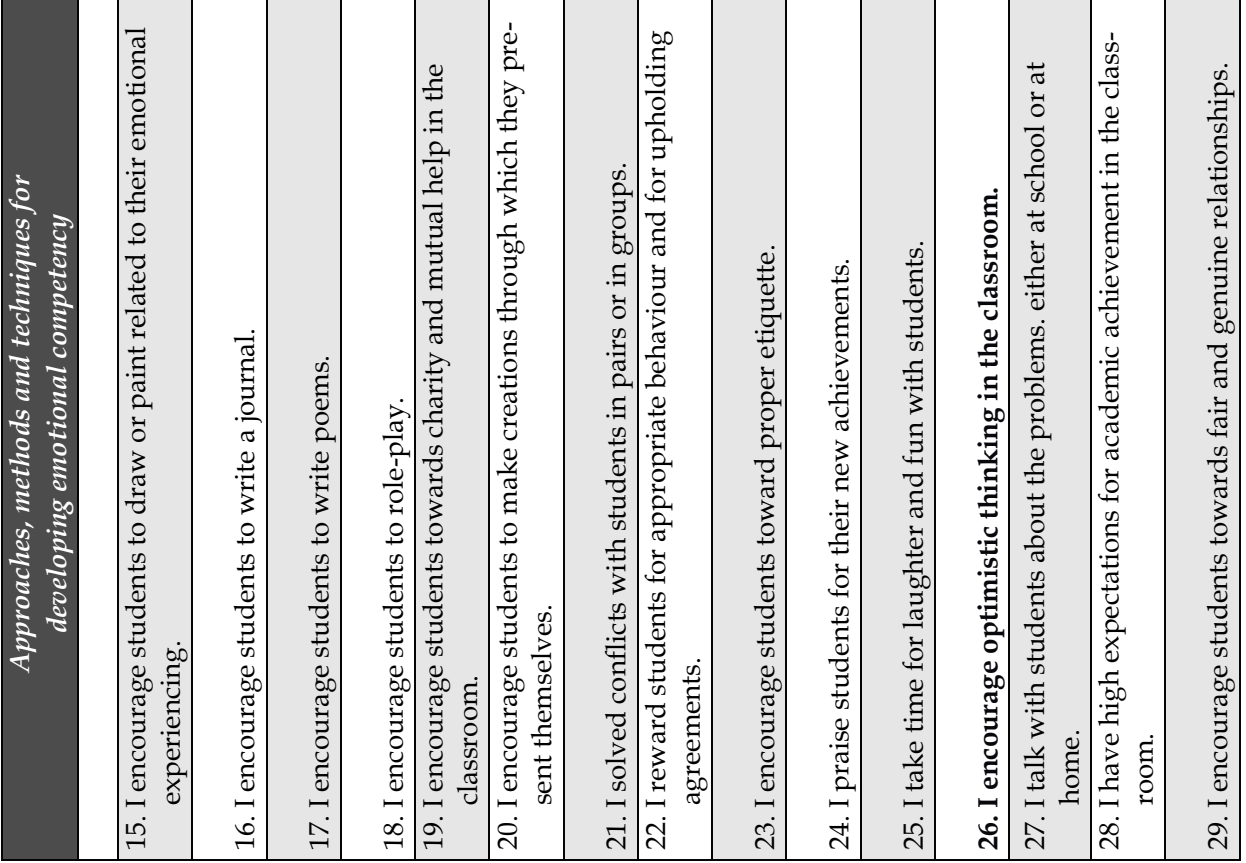




\section{Conclusions}

For the development of their potentials, students need a stimulating learning environment, which in the context of schooling is mainly the responsibility of pedagogical workers. Teachers and social pedagogues are in daily contact with students, enabling them to connect the curriculum with the topic of emotions and social relationships. They can encourage students to cooperate and be tolerant, to control their emotions, resolve conflicts, etc. As research findings shows that social and emotional competencies influence several dimensions of schooling: teacher-student relationships, classroom management, effectiveness of instruction, teacher's burnout etc. There is good reason to believe that social and emotional competencies like managing emotions and stress are more needed today than ever before ${ }^{41}$. Using different approaches, teachers and social pedagogues can contribute to everyday development of students' emotional and social skills, which will be useful later in life, especially during adolescence.

In this research, we tried to find out how often teachers and social pedagogues use certain approaches, methods and techniques for stimulating emotional competency of students, and where there are differences between the two professional profiles. When designing the questionnaire we considered the professional findings of Bisquerry Alzina et al., who group the approaches, methods and techniques into multiple groups: awareness of emotions, control of emotions, emotional autonomy, emotionally-social skills and emotional skills for social well-being. ${ }^{22}$ Our results show that both teachers and social pedagogues most often use the approaches for encouraging emotionally-social skills and skills for social well-being. We found that social pedagogues more often encourage the intra-personal skills of students. They tend to encourage students towards awareness of their emotions, describing the emotions and feelings the fell in relation to a certain topic, towards reading stories and tales on the topic of emotions, and they more often encourage students towards optimistic views. Both profiles, on the other hand, least often encourage emotion control and especially emotional autonomy.

We should note the importance of cooperation between teachers and social pedagogues, which greatly depends on the awareness of the important of development of emotional competencies with the intension of »equipping « themselves and students with competencies in the area. All pedagogical workers should be actively familiar with the topic of emotional intelligence; it should be discussed at team meetings, working groups, supervisor

41 S.M. Jones, S.M. Bouffard, R. Weissbourd, Educators' social and emotional skills vital to learning, Kappanmagazine, 2013, 94/8.

42 R. Bisquerra Alzina et al., Čustvena inteligenca otrok. 
meetings etc. Acknowledging the importance of developing social and emotional learning in schools, the question that arises next is which skills should be taught to students, how they should be prioritized and by which pedagogical approaches, methods and techniques should they be implemented. Triliva and Poulou stated that there is a great range and breadth of skills that researchers have argued for, from tolerance for students with different lifestyles to skills for dealing with high-risk behaviours or skills for social interaction. ${ }^{43}$ A review of studies on competence-based programmes revealed a lack of research on teachers' perceptions or understandings regarding the development or implementation of social and emotional skills programming within school settings. This is rather surprising since it is assumed that the active participation of school personnel, and especially teachers, is a prerequisite of the successful implementation of these programmes. ${ }^{44}$ Research findings also show that teacher' implicit theories and understandings have a significant impact on their approaches to teaching, how they interact with students' and children's achievement ${ }^{45}$. Teachers' attitudes towards the educational trend of implementing social and emotional learning in schools becomes crucial as it is the case in any programme implementation attempted within school limits.

Using different approaches, teachers contribute towards the development of emotional and social skills of students, which will be of great help to them later in life. Social pedagogues have well-developed competencies in the area of working with individuals and groups, with they can act preemptively in many ways, including prevention of violence in schools. Their task is to connect with different subsystems within the school, e.g. school leadership, teachers, other expert workers, parents and students. With their expert attention to different topics, social pedagogues educate individuals and groups to stimulate emotional competency of students in different ways. The possibilities for developing emotional competency in the classroom are both numerous and diverse, e.g. talking about emotions, considering the special needs of each individual, encouraging tolerance, encouraging miming, reading stories, writing poems, creating, etc. One possibility is a design of a new school subject with the aim of developing emotional and social skills and therefore emotional competency. A necessary precondition of such a function is awareness of the importance of development of emotional competency in both educators and students during their formal education.

${ }^{43}$ S. Triliva, M. Poulou, Greek Teachers' Understandings and Constructions of What Constitutes Social an Emotional Learning, School Psychology International, 2006, 27/3.

${ }^{44}$ Ibidem.

${ }^{45}$ B.J. Sheehan, M.A. McDonald, K.K. Spence, Developing Students' Emotional Competency. 


\section{BIBLIOGRAPHY}

Arghode V., Emotional and social intelligence competence: Implications for instruction, International Journal of Pedagogies and Learning, 2014, 8/2.

Bellhouse B., Johnson G., Fuller A., Empathy: promoting resilience and emotional intelligence for young people aged 7 to II, Paul Chapman, Thousand Oaks, London 2005.

Bisquerra Alzina R., Perez Escoda N., Cuadrado Bonilla M., Lopez Cassa E., Filella Guiu G., Obiols Soler M., Čustvena inteligenca otrok: priročnik za učitelje in starše z vajami, Tehniška založba Slovenije, Ljubljana 2010.

Brackett A.M., Rivers E.S., Salovey P., Emotional intelligence: implications for personal, social, academic and workplace success, Social and personality psychology Compass 2011, 5.

Bradberry T., Greaves J., Čustvena inteligenca: kratek vodnik, Tuma, Ljubljana 2008.

Brearley M., Emotional intelligence in the classroom: creative learning strategies for 11-18s, Crown House Publishing, Carmarthen 2001.

Gardner H., The frames of mind, Basic Books, A division of HarperCollins Publishers Inc. 1993.

Goleman D., Čustvena inteligenca: zakaj je lahko pomembnejša od IQ, Založba Mladinska knjiga, Ljubljana 1997.

Goleman D., Working with emotional intelligence, Bantam Books, New York, Toronto, London, Sydney, Auckland 2000.

Grünfeld T., Socialni pedagog v osnovni šoli, Socialna pedagogika, 1997, 1/4.

Jeriček Klajnšček H., Ko učenca strese stres in kaj pri tem lahko naredi učitelj.Priročnik za učitelje in svetovalne delavce, Inštitut za varovanje zdravja RS, Ljubljana 2007.

Jones S.M, Bouffard S.M., Weissbourd R., Educators' social and emotional skills vital to learning, Kappanmagazine, 2013, 94/8.

Matthews G., Zeidner M., Roberts R.D., Emotional Intelligence: science and myth, MIT Press, Cambridge-London 2004.

Panju M., Strategije za spodbujanje čustvene inteligentnosti v razredu, Modrijan, Ljubljana 2008.

Pečjak S., Avsec A., Konstrukt emocionalne inteligentnosti, Psihološka obzorja, 2003,12/1.

Pečjak S., Košir K., Povezanost čustvene inteligentnosti z nekaterimi vidiki psihosocialnega funkcioniranja pri učencih osnovne in srednje šole, Psihološka obzorja, 2012, 12/1.

Sheehan B.J., McDonald M.A., Spence K.K., Developing Students' Emotional Competency Using the Classroom - as Organization Approach, Journal of Management Education, 2009, 33/1.

Schilling D., 50 dejavnosti za razvijanje čustvene intelligence, Inštitut za razvijanje osebne kakovosti, Ljubljana 2000.

Shapiro E.L., Čustvena inteligenca otrok: kako vzgojimo otroka z visokim čustvenim količnikom, Mladinska knjiga, Ljubljana 1999.

Simmons S., Simmons C.J., Merjenje čustvene intelligence, Mladinska knjiga, Ljubljana 2000.

Triliva S., Poulou M., Greek Teachers' Understandings and Constructions of What Constitutes Social an Emotional Learning, School Psychology International, 2006, 27/3.

Warden D., Christie D., Spodbujanje socialnega vedenja: dejavnosti za spodbujanje prosocialnih medosebnih spretnosti in vedenja, Inštitut za psihologijo osebnosti, Ljubljana 2001. 
Weare K., Developing the emotionally literate school, Paul Chapman Publishing, London 2004.

Weisbach C., Dachs U., Kako razvijamo čustveno inteligenco: razmišljajmo s srcem, DZS, Ljubljana 1999.

Wharam J., Čustvena inteligenca: potovanje v središče samega sebe, Anu Elara, Ig 2012.

Wood R., Tolley H., Ocenite svojo čustveno inteligenco: kako določiti in povečati svojo čustveno inteligenco? Lisac \& Lisac, Ljubljana 2004. 